\title{
Setting the Minimum Wage in the Russian Federation Regions
}

\author{
Ajupov A.A. ${ }^{a}$ \\ Kurilova A.A.b \\ Efimova E.A.c \\ a Kazan Federal University, Institute of Management, Economics and Finance, Kazan, 420008, Russia \\ ${ }^{\text {b} T o g l i a t t i ~ S t a t e ~ U n i v e r s i t y, ~ T o g l i a t t i, ~ 445667, ~ R u s s i a ~}$ \\ cSamara State Aerospace University, Samara, 443086, Russia \\ Email: aakurilova@yandex.ru
}

\section{Doi:10.5901/mjss.2015.v6n1s3p35}

\begin{abstract}
Authors investigate the historical aspect of the minimum wage setting in Russia. It is noted that in the USSR period the minimum wage was not aimed at the labour market regulation, but on the structuring of the salary system in the Soviet economy. At the present time the minimum wage in Russia and its regions not solve its main objective - to provide a simple reproduction of the labour force of low-skilled workers. Different ways of the minimum wage setting in the regions of Russia have led to significant territorial differentiation. The authors suggest some measures to improve the minimum wage setting in Russia.
\end{abstract}

Keywords: minimum wage, labour market, region, unemployment, wages.

\section{Introduction}

An important measure of labour market regulation in the Russian Federation is the practice of minimum wage establishing by the state. According to article 133 of the Labour Code of the Russian Federation, the minimum wage may not be lower than the cost of living of an able-bodied person, however, this provision has not yet been implemented. The discussion on the necessity and feasibility of the minimum wage increasing continua in academic and political circles.

The purpose of this paper is to study the practice of setting the minimum wage in the Russian Federation and to develop recommendations to improve the mechanism of the labour market regulation by a minimum wage setting.

The Russian Federation has developed a unique practice of establishing a minimum wage at different levels of government. So at the federal level, the minimum wage is set by law at the initiative of the Russian Federation Government, and in the Russian Federation regions - on the basis of tripartite agreements of the social partners (regional executive authorities, employers and workers). The federal minimum wage, like in most countries of the world, applies to all categories of employees in all sectors of the economy.

\section{Theory}

Established in Russian practice of setting the minimum wage has Soviet "roots". Minimum wages in USSR times was not considered as the lower limit of the labour price in the labour market, because de facto the labour market in the Soviet period did not exist. Its main significance was in structuring a system of salaries of the employed population in the Soviet economy. The minimum wage corresponded to the minimum rate Unified tariff intended for wage worker first category operating in normal conditions and performs labour standards or spent time rate.

First tariff wage system was introduced for railway workers in 1917 by People's Commissars Council decree "On the norms of remuneration railwaymen categories of employees and eight-hour day in all branches of railway work", according to which fourteen categories of employees were introduced, where the rate of the first category corresponded salary of 155 rubles and fourteens categories - 510 rubles. April 1, 1918 was adopted People's Commissars Council decree "On the introduction of rates on the People's Commissars Council according to the tariffs approved by the People's Commissariat of Labour," in which all employees are divided into three categories: non-qualified employees, qualified employees and persons intelligent labour (doctors, workers in the education, heads of educational institutions, 
heads of departments, engineers, etc.) for the latest category of persons establish the salary of 700 rubles a month, and for the first category persons - 275 rubles per month, which corresponds to the minimum rate of pay.

A new approach to the wages regulation of all employees was established by Decree People's Commissars Council from October 18, 1918 "On the payment of employees and workers of Soviet institutions", according to which the tariff wages system was introduced: all the employees were divided into 4 groups depending on their qualification level and specialized knowledge; in each group were allocated to 3 categories of workers, depending on experience and seniority. The most highly paid employees of the first group of the first category received 1,000 rubles per month, and the lowest-paid workers in group 4 category 3 - 475 rubles per month.

Do not think that the Soviet government made significant progress in raising the minimum wage. However, it must be borne in mind that while only about $7 \%$ of wages to employees paid in cash and the other part of wages workers received in products. In particular, according to the Decree of People's Commissars Council from October 18, 1918 "On the payment of employees and workers of Soviet institutions" all kinds of renditions of Employees include in wages: food items and using of apartment, utilities, public transport and even hairdressing and baths - in the amount of their actual value at that time.

During the first years of USSR tariff system of remuneration was a subject to constant change, and with it waS changing the minimum wage. This was due to the fact that in the period of war communism in the USSR increased dramatically currency issue, which resulted in a rise in food prices, and that, ultimately, led to the introduction of the rationing system. To restore the monetary system of the country in 1922 - 1924 years held the first monetary reform. Thus, a ruble of 1923 was equivalent to a million old rubles and 100 rubles of 1922. Introduction of a new monetary system and gold pieces entailed changing wage systems. There were excluded non-cash forms of payment of wages to workers. Wages are set by collective agreements for each group of occupations, concluded between the administrations of enterprises and workers unions. Since 1926 there has been a steady growth in the USSR minimum wage. In 1926, the average for the economy, minimum wage was 0,82 rubles per day in $1927-0,91$ rubles, in $1928-1,26$ rubles per day.

On November 1, 1937 the minimum wage on the USSR territory is set at 115 rubles per month for employees working on the terms of hourly wages, and 110 rubles for workers working on the terms of piecework pay system.

During the Great Patriotic War natural employee benefits and rationing were mainly used. In the postwar period, all sectors of the economy had their tariff schedules. Reform outdated tariff system, which existed for over 20 years, was conducted in 1956 - 1964. During this time, the amount was reduced tariff scales applied in industries with a few thousand to twelve. The system of remuneration has become clear and understandable for each employee. It links its qualifications, conditions and results with the value of labour wages.

In 1961 the next monetary reform in the Soviet Union was held, at which the specimen banknotes in 1947 were exchanged for new ones in a ratio of 10: 1. In the same proportion were changed and wages, social security benefits, pensions, and the prices of all commodities. In 1964, the minimum wage in all sectors of the national economy was 40 45 rubles. From January 1, 1968 the minimum monthly wage of workers and employees of all sectors of the economy has been increased to 60 rubles. In 1972, the minimum wage according to the decree of the Central Committee of the Communist Party and the USSR Council of Ministers Council of Trade Unions was already 70 rubles. It existed until October 1, 1991.

USSR Law of 19 April 1991 "On improving social guarantees for workers' minimum wage in Russia was raised to 180 rubles a month. The uncontrolled growth of prices in 1991 - 1997 years contributed to constant revision of the minimum wage by the Russian Federation Government. During the period of market reforms from 1991 till 1997, the minimum wage has changed seventeen times, and it has grown to 464 times. From January 1, 1997, it was set at 83490 denominated rubles per month. Lack of necessary funds in the federal budget for raising the minimum wage after the 1998 default made it impossible to revise its value until June 2000. Federal law from June 19, 2000 about the minimum wage in Russia was raised to 132 rubles, and from that moment began its gradual growth and increased purchasing power in relation to the cost of living (see table 1).

Table 1: The ratio of the minimum wage and the cost of living established at the level of the Russian Federation

\begin{tabular}{|l|c|c|c|}
\hline $\begin{array}{l}\text { Date of the minimum } \\
\text { wage revision }\end{array}$ & $\begin{array}{c}\text { Minimum wage, } \\
\text { rub. monthly }\end{array}$ & $\begin{array}{c}\text { The cost of living of an able- } \\
\text { bodied person, rub. monthly }\end{array}$ & $\begin{array}{c}\text { The ratio of the minimum wage } \\
\text { and cost of living, } \%\end{array}$ \\
\hline 1 January 2014 & 5554 & 8283 & 67,05 \\
\hline 1 January 2013 & 5205 & 7633 & 68,19 \\
\hline 1 June 2011 & 4661 & 7023 & 66,37 \\
\hline 1 January 2009 & 4330 & 5497 & 78,77 \\
\hline
\end{tabular}




\begin{tabular}{|l|c|c|c|}
\hline $\begin{array}{l}\text { Date of the minimum } \\
\text { wage revision }\end{array}$ & $\begin{array}{c}\text { Minimum wage, } \\
\text { rub. monthly }\end{array}$ & $\begin{array}{c}\text { The cost of living of an able- } \\
\text { bodied person, rub. monthly }\end{array}$ & $\begin{array}{c}\text { The ratio of the minimum wage } \\
\text { and cost of living, } \%\end{array}$ \\
\hline 1 September 2007 & 2300 & 4330 & 53,12 \\
\hline 1 May 2006 & 1100 & 3717 & 29,59 \\
\hline 1 September 2005 & 800 & 3288 & 24,33 \\
\hline 1 January 2005 & 720 & 3138 & 22,58 \\
\hline 1 October 2003 & 600 & 2341 & 25,63 \\
\hline 1 May 2002 & 450 & 1865 & 24,12 \\
\hline 1 July 2001 & 300 & 1635 & 18,35 \\
\hline 1 January 2001 & 200 & 1513 & 13,22 \\
\hline 1 July 2000 & 132 & 1290 & 10,23 \\
\hline
\end{tabular}

Since 2007, Russia has changed the economic content of the concept of "minimum wage". In the USSR period there was a practice of establishing the minimum wage as a part of the earnings of the employee, to which various payments and allowances were added, depending on the qualifications of the employee, complexity, quantity, quality and working conditions. This practice was eliminated relatively recently after the introduction of the 2007 amendments to Article 129 of the Labour Code, according to which of this Article was removed the very definition of the minimum wage, with the position that a minimum wage is not included compensation, incentives and social benefits. Therefore, at the present time the minimum wage includes all kinds of those benefits. Changing this provision has caused many disputes and even litigation, especially among the population employed in areas with difficult climatic conditions, as well as in the production of heavy, hazardous or dangerous conditions. However, the new version of Article 129 of the Labour Code was left unchanged.

Thus, at the federal level the law is not enforced norm of Article 133 of the Labour Code that the minimum wage cannot be below the minimum subsistence level. However, in some regions of the Federation, this provision is a practical embodiment, and their experience of establishing a minimum wage can be used by other Russian Federation regions.

\section{Results}

The understanding that the minimum wage can not be the same in the Russian Federation regions because of the huge territorial extent of the country and different climatic conditions, has led to the fact that since 2005 the individual Russian Federation regions was granted right to establish the regional minimum wage, based on their economic opportunities.

Federal Law of June 19, 2000 "On the minimum wage" from 1 January 2005 at the federal level was established a minimum wage of 720 rubles, and from 1 September 2005 - 800 rubles per month. However, self-sufficient entities of the Russian Federation (which did not receive subsidies from the federal budget) were allowed to make their own laws and establish a higher minimum wage than the federal. These laws were to take into account the views of the tripartite commission for regulation of social and labour relations in the region. First specified rule of law in 2005 benefited Moscow and St. Petersburg.

On September 1, 2007 in accordance with Article 133.1 of the Labour Code of the Russian Federation all subjects of the Federation have the right to establish a regional minimum wage, which must not be less than the federal. To do this they need to provide a regional tripartite agreement between the Government of the Federation, the employers' association and union workers.

The minimum wage in the regions can be established for all workers employed in the territory of the subject of the Federation, except for employees, organizations which are financed from the federal budget. Setting the minimum wage Russian Federation regions should proceed from the socio-economic conditions and the subsistence level of the working population prevailing in the region.

Despite a legislative basis in Article 133 of the Russian Labour Code provisions that the minimum wage can not be below the minimum subsistence level of the working population, the majority of the Russian Federation regions are in no hurry to raise the minimum wage, and use the level set for the Russian Federation. Regional authorities do not want to burden their budgets additional cost to payments of the minimum wage. There is only a region where the minimum wage is established at the cost of living of an able-bodied person in all sectors of the economy, it is the Kamchatka Region.

The lack of common and clearly defined mechanism, to set minimum wages at the regional level has led to three approaches (methods) to establish a minimum wage in the Russian regions:

1. The minimum wage is set at the level of federal significance. This is the most common variant of the minimum wage setting in the Russian Federation regions. It is in no way affiliated with the regional estimates the cost of 
living and, therefore, is not a guarantee of social protection against poverty for the working population. But as the legislation of the Russian Federation does not contain the conditions under which the subject of Federation would be obliged to set minimum wages above the federal level, this method is used and the subsidized regions of the North Caucasus Federal District, and it is secured in the Central and Volga Federal District, and the regions with difficult climatic conditions of the Siberian and Far Eastern Federal District.

2. The minimum wage is set as a percentage of the cost of living of an able-bodied population in the region. Typically, this ratio is $100 \%$. There is only a region to set a minimum wage at the level of $120 \%$ of the cost of living level, it is the Volgograd Region. As already noted, this social standard in most regions only applies to workers in the private sector.

3. The minimum wage is set as a fixed amount. This practice is more convenient, especially for employers who do not need to constantly monitor the dynamics of the cost of living, established by regional authorities on the expiration of the next quarter, and then compensate for low-paid workers underpaid amount spent for the period. Moreover, in those regions of the Federation, where applicable fixed minimum wage, it is mandatory for employers of all sectors of the economy, but unfortunately it is often lower than the cost of living, because of the limited financial capacity of the regional budgets.

The Russian Federation regions have the right to set a minimum wage below the federal level or even eliminate the use of the minimum wage in their territory (see table 2).

Table 2: The distribution of the subjects of the Russian Federation according to the methods of establishing the minimum wage in 2013

\begin{tabular}{|l|l|}
\hline $\begin{array}{l}\text { A method for establishing } \\
\text { minimum wage }\end{array}$ & Regions \\
\hline \multirow{5}{*}{$\begin{array}{l}\text { Minimum wage is the federal } \\
\text { level (5205 rubles). }\end{array}$} & $\begin{array}{l}\text { Belgorod Region, Bryansk Region, Voronezh Region, Tula Region, Yaroslavl Region, Rostov } \\
\text { Region, Mordovia Republic, Chuvashia Republic, Chelyabinsk Region, Khakassia Republic, } \\
\text { Transbaikalia territory, Kemerovo Region, Vladimir Region, Smolensk Region, Tambov } \\
\text { Region, Vologda Region, Mari El Republic, Tatarstan Republic, Nizhny Novgorod Region, } \\
\text { Orenburg Region, Sverdlovsk Region, Tyumen Region, Buryatia Republic, Krasnoyarsk }\end{array}$ \\
& $\begin{array}{l}\text { Region, Irkutsk Region, Ivanovo Region, Kostroma Region, Lipetsk Region, Orel Region, } \\
\text { Komi Republic, Novgorod Region, Pskov Region, Dagestan Republic, Ingushetia Republic, } \\
\text { Kabardino-Balkar Republic, Karachay-Cherkess Republic, North Ossetia - Alania Republic, } \\
\text { Chechen Republic, Stavropol Region, Adygea Republic, Kalmykia Republic, Astrakhan }\end{array}$ \\
& $\begin{array}{l}\text { Region, Bashkortostan Republic, Udmurtia Republic, Perm Region, Kirov Region, Penza } \\
\text { Region, Samara Region, Saratov Region, Kurgan Region, Tyva Republic, Omsk Region, } \\
\text { Jewish Region, Chukotka Region }\end{array}$ \\
\hline \multirow{5}{*}{$\begin{array}{l}\text { Minimum wage as a fixed } \\
\text { amount }\end{array}$} & $\begin{array}{l}\text { Moscow, St. Petersburg, Moscow Region, The Ryazan Region, Karelia Republic, } \\
\text { Arkhangelsk Region, Nenets Region, Kaliningrad Region, Leningrad Region, Murmansk }\end{array}$ \\
& Region, Khanty-Mansiysk and Yamal-Nenets, Altay Region, Tomsk Region, Novosibirsk \\
& Region, Khabarovsk Krai, Sakhalin Region, Sakha (Yakutia) Republic, Magadan Region, \\
& Resp. Altai, Amur Region. \\
\hline $\begin{array}{l}\text { As a percentage of the minimum } \\
\text { wage to a living cost }\end{array}$ & Kaluga Region, Volgograd Region, Kursk Region, Tver Region, Krasnodar Region, \\
& Ulyanovsk Region, Kamchatka, Primorsky Region \\
\hline
\end{tabular}

Russia is unlikely to achieve a substantial improvement of living standards until such an important social standard as the minimum wage, which serves as a kind of "point of reference" for the wage-setting all the categories of the employed population and the size of temporary disability benefits, is so low that it does not allow meet the vital needs of the employee and provide even simple reproduction of his labour.

Unlike many other countries in Russia there is no applicable subminimum wage for youth, and there are no workers for whom the minimum wage does not apply (for example, persons with disabilities). It is in practice reduces the possibility of employment specified categories of workers.

Labour Code does not provide guidance as to when and under what conditions should be revised minimum wage. Article 134 of the Russian Labour Code contains a provision according to which wages (not just the minimum) should be indexed by employers with the growth of consumer prices for goods and services, however, in practice, this provision is not implemented any budget organizations or private firms. As a result, the minimum wage is reviewed periodically at the discretion of the Government. Such practices have often been criticized by Russian researchers.

Given that Russia is an important player in the global labour market and is involved in the processes of 
international migration exchange existing in the Russian system of setting the minimum wage needs to be reformed based on the experience of developed countries and the modern needs of the Russian economy in attracting foreign labour on the Russian labour market.

\section{Conclusions}

The Government of the Russian Federation has the task of making the minimum wage the social standard that would provide employment to population welfare, sufficient for the reproduction of their labour. The analysis of minimum wages in the subjects of the Russian Federation indicated that the region has not produced any single approach to the determination of its amount. In many regions of the Federation minimum wage remains below the subsistence level. This fact has a negative impact on the ability of reproduction of the labour force of low-skilled workers. Under these circumstances it is necessary to implement these measures.

Firstly, given that the Russian Federation has developed various ways of setting the minimum wage, which create unequal opportunities for low-wage workers in the maintenance of an acceptable level of life, there is a need to develop a common approach to the establishment of the minimum wage across the country. The minimum wage as a social standard should depend only on the conditions of employment and the necessary costs of reproduction of labour power of the employed population, and should not depend on the selected region's ability to establish a minimum wage. In this regard, at the federal level, it is advisable to develop a common methodology for setting the minimum wage in the Russian Federation, which must have prescribed criteria for establishing and raising the minimum wage, such as, for example, the rising cost of living, the expected rate of inflation, the dynamics of labour productivity .

Secondly, it is necessary to review the provisions of Article 129 and 133 of the Russian Labour Code. In our opinion, the minimum wage should not include compensation and incentive payments and allowances. If, for example, enabling premium is included in the minimum wage, then it ceases to be a premium in the conventional sense of the term, and loses its stimulatory. In the current environment the workers no incentive to work in the factories, where the working conditions are different from normal.

Third, in Russia there is a need for the introduction of a special minimum wage for young workers first hired. Since the performance of the young workers are traditionally lower than that of workers with experience, therefore, their wages must also be different. This will increase the incentives for Russian employers to hire young staff.

\section{References}

Azar Ofer $\mathrm{H}$. The effect of the minimum wage for tipped workers on firm strategy, employees and social welfare // Labour Economics, Volume 19, Issue 5, October 2012. Pp. 748-755.

Addison John T., Blackburn McKinley L., Cotti Chad D. Minimum wage increases in a recessionary environment // Labour Economics, Volume 23, August 2013. Pp 30-39.

Boeri T. Setting the minimum wage // Labour Economics, Volume 19, Issue 3, June 2012. Pp. 281-290.

Danziger L. Noncompliance and the effects of the minimum wage on hours and welfare in competitive labor markets // Labour Economics, Volume 16, Issue 6, December 2009. Pp. 625-630.

Zavodny M. The effect of the minimum wage on employment and hours // Labour Economics, Volume 7, Issue 6, November 2000. Pp. $729-750$.

Kumar A. Capital tax, minimum wage, and labor market outcomes // Review of Economic Dynamics, Volume 11, Issue 1, January 2008. Pp.133-154.

Larraín M., Poblete J. Age-differentiated minimum wages in developing countries // Journal of Development Economics, Volume 84, Issue 2, November 2007. Pp. 777-797.

Lemos S. Minimum wage effects in a developing countryOriginal Research Article // Labour Economics, Volume 16, Issue 2, April 2009. Pp.s 224-237.

Petrakis E., Vlassis M. The endogenous national minimum wage institution // Journal of Macroeconomics, Volume 27, Issue 4, December 2005. Pp. 747-762.

Satchi M., Temple J. Labor markets and productivity in developing countries // Review of Economic Dynamics, Volume 12, Issue 1, January 2009. Pp. 183-204.

Adigamova Farida F., Safiullin Marat A., Tufetulov Aidar M. Mechanism of state tax regulation in the global economy // Mediterranean Journal of Social Sciences vol. 5 № 24, November 2014, pp. 193-199.

Valitov S.M., Nigmetzyanov A.A. New requirements of the basel committeee on banking supervision to capital as a measure to ensure the stability of the banking sector // Mediterranean Journal of Social Sciences vol. 5 № 24, November 2014, pp. 294-299. 